\title{
Pentingnya Modal Kerja Dalam Meningkatkan Usaha Nelayan Di Kampung Ngalipaeng II Kecamatan Manganitu Selatan Kabupaten Kepulauan Sangihe
}

\author{
Claudia Ayu Manumpil \\ Tinneke M. Tumbel \\ Joan V. Mangindaan \\ Program Studi Administrasi Bisnis, Jurusan Ilmu Administrasi \\ Fakultas Ilmu Sosial dan Ilmu Politik Universitas Sam Ratulangi Manado \\ Email : claudiaayu270595@gmail.com
}

\begin{abstract}
ABSTRAK
The purpose of this study was to determine the business conditions of fishing communities in Ngalipaeng II village. This research is a type of qualitative research. In coastal communities, traditional fishermen are the most suffering, poor and often the victims of the marginalization process due to fisheries modernization policies. In general, the so-called traditional fishermen are fishermen who utilize fishery resources with traditional fishing equipment, small business capital, and relatively simple fishing organizations. In general, fishermen still experience limited fishing technology. With a simple fishing gear, the operational area becomes limited, only around the coastal waters. Another problem is that access to markets is often not owned by fishermen, especially fishermen who live on small islands. Meanwhile, the condition of fish that easily rot, is a big problem faced by traditional fishermen. The income earned by these fishermen is generally used to fulfill the basic needs of family members. The basic needs that are intended in this case are food, clothing and housing as basic needs that are very important for survival, as well as social needs such as activities for merry, thanksgiving and others. Many fishing communities have not been able to meet the needs of household life, education, and other needs. Because given the results of fishing businesses that are so low / less because of limited costs and working capital.
\end{abstract}

Keywords: Ngalipaeng II Village, Working Capital, Fisherman

\section{Pendahuluan}

Masyarakat Nelayan identik dengan kemiskinan, banyak hal yang menyebabkannya yaitu kurangnya modal usaha yang dimiliki para nelayan lebih khusus usaha hasil nelayan. Salah satunya yaitu kurangnya modal kerja juga merupakan hal yang mempengaruhi pendapatan nelayan. Dengan tidak tersedianya modal kerja yang memadai maka nelayan tidak akan mampu meningkatkan produksi serta biaya operasional. Hal ini akan menjadikan produktifitas nelayan menurun. Masyarakat nelayan merupakan salah satu bagian mayarakat Indonesia yang hidup dengan mengelola sumber daya perikanan. Sektor perikanan pada hakekatnya dapat dikembangkan sebagai alternatif bagi perbaikan ekonomi masyarakat nelayan. 
Biasanya selesai dari melaut tidak ada kegiatan dalam upaya menambah pendapatan, kegitan rutinitas seperti ini dilakukan untuk kehidupan sehari-hari. Persoalan tersebut telah dilakukan oleh seluruh nelayan, bahkan ada beberapa keluarga nelayan dengan mendayagunakan segala potensi atau sumberdaya yang tersedia pada keluarga, seperti melakukan pekerjaan sampingan setelah pulang dari melaut sebagai tukang ojek, buruh tani, dan ada beberapa nelayan yang anggota keluarganya membantu bekerja untuk mendapatkan penghasilan sepereti ibu rumah tangga berdagang dengan modal kecil, dan lain-lain. Kurangnya modal usaha merupakan hal yang mempengaruhi rendahnya pendapatan nelayan. Dengan tidak tersedianya modal yang memadai maka nelayan tidak akan mampu meningkatkan produksi karena nelayan tidak bisa membeli perahu, alat tangkap dan peralatan lainnya, serta biaya operasional juga tidak akan terpenuhi dan akan menjadikan produktifitas nelayan menurun, sehingga pendapatan akan mengalami perubahan bahkan akan mengalami penurunan jika terjadi inflasi, sehingga daya beli masyarakat nelayan menjadi rendah yang akan mengakibatkan tingkat kesejahteraan yang semakin rendah yang artinya pendapatan bergantung pada modal hal ini berarti dengan adanya modal maka nelayan dapat melaut untuk menangkap ikan. Semakin besar modal maka makin besar pula peluang hasil tangkapan yang diperoleh.

Berdasarkan uraian pada latar belakang tersebut dan dalam rangka meningkatkan usaha nelayan di kampung Ngalipaeng kecamatan manganitu selatan kabupaten kepulauan sangihe, penulis tertarik memilih judul : "Pentingnya modal kerja dalam meningkatkan usaha nelayan di Kampung Ngalipaeng kecamatan manganitu selatan kabupaten kepulauan sangihe".

\section{Usaha Kecil}

Usaha kecil adalah kegiatan ekonomi rakyat yang berskala kecil, dan memenuhi kekayaan bersih atau hasil penjualan tahunan serta kepemilikan sebagaimana diatur dalam undang-undang (Tohar, 2001:1). Menurut Ina Primiana mendefinisikan usaha kecil adalah sebagai berikut (Primiana, 2009:11):

1. Pengembangan empat kegiatan ekonomi utama (core business) yang menjadi motor penggerak pembangunan, yaitu agribisnis, industri manufaktur, sumber daya manusia (SDM), dan bisnis kelautan.

2. Pengembangan kawasan andalan, untuk dapat mempercepat pemulihan 
perekonomian melalui pendekatan wilayah atau daerah, yaitu dengan pemilihan wilayah atau daerah untuk mewadahi program prioritas dan pengembangan sektor-sektor dan potensi.

3. Peningkatan upaya-upaya pemberdayaan masyarakat.

\section{Nelayan}

Sastrawijaya (2002:42) mengatakan komunitas nelayan adalah kelompok orang yang bermata pencaharian hasil laut dan tinggal di desa-desa pantai atau pesisir. Ciri-ciri komunitas nelayan dapat dilihat dari berbagai segi sebagai berikut:

1. Dari segi mata pencaharian, nelayan adalah mereka yang segala aktivitasnya berkaitan dengan lingkungan laut dan pesisir atau mereka yang menjadikan perikanan sebagai mata pencaharian mereka.

2. Dari segi cara hidup, komunitas nelayan adalah komunitas gotong royong. Kebutuhan gotong royong dan tolong menolong terasa sangat penting pada saat mengatasi keadaan yang menuntuk pengeluaran biaya besar dan pengarahan tenaga kerja yang banyak, seperti saat berlayar, membangun rumah atau tanggul penahan gelombang disekitar pantai.
3. Dari segi keterampilan, meski pekerjaan nelayan adalah pekerjaan berat namun pada umumnya mereka hanya memiliki keterampilan yang sederhana. Kebanyakan mereka bekerja sebagai nelayan adalah profesi yang diturunkan oleh orang tua, bukan yang dipelajari secara relative.

Berdasarkan definisi diatas maka dapat disimpulkan bahwa nelayan adalah suatu komunitas yang mana mata pencaharian utamanya adalah menangkap ikan, baik di laut, selat, teluk, danau maupun sungai dengan menggunakan perahu atau kapal dan berburu atau menggunakan perangkap. Mereka umumnya tinggal atau menetap di daerah pesisir pantai dan membentuk suatu komunitas yang disebut dengan komunitas nelayan. Mereka adalah orang-orang yang begitu gigih dan akrab dengan kehidupan di laut yang sifatnya keras.

\section{Nelayan Tradisional}

Nelayan tradisional adalah kelompok yang paling menderita, miskin dan acapkali merupakan korban proses marginalisasi akibat kebijakan modernisasi perikanan. Secara umum, yang disebut nelayan tradisional adalah nelayan yang memanfaatkan sumber daya perikanan dengan peralatan tangkap tradisional, modal usaha yang kecil, dan organisasi 
penangkapan yang relative sederhana.

Dalam perkembangannya nelayan telah terkait dengan relativ sesuai dengan perkembangan IPTEK selama ini. Nelayan tradisional juga di sebut sebagai orang yang bergerak di sektor kelautan dengan menggunakan perahu layar tanpa motor (Mulyadi 2005, 173). Dapat dipahami, jika ketergantungan nelayan terhadap teknologi penangkapan itu sangat tinggi. Hal tersebut disebabkan selain kondisi sumber daya perikanan yang bersifat mobile, yaitu mudah berpindah dari satu tempat ketempat yang lain, juga untuk menangkapnya nelayan perlu sarana bantu untuk dapat bertahan lama hidup di atas air. Pada umumnya para nelayan masih mengalami keterbatasan teknologi penangkapan. Dengan alat tangkap yang sederhana, wilayah operasi pun menjadi terbatas, hanya di sekitaran perairan pantai.

\section{Kemiskinan Nelayan dan Faktor-faktor}

\section{Kemiskinan Nelayan}

$\begin{array}{llr}\text { Kemiskinan } & \text { nelayan } & \text { cenderung } \\ \text { dialami oleh nelayan } & \text { perorangan } \\ \text { (tradisional) dan } & \text { buruh nelayan.Karena }\end{array}$
kedua jenis kelompok jenis itu jumlahnya mayoritas, citra tentang kemiskinan melekat pada kehidupan nelayan. Dilihat dari lingkupnya, kemiskinan nelayan terdiri atas kemiskinan prasarana dan kemiskinan keluarga. Kemiskinan prasarana dapat diindikasikan pada ketersediaan prasarana fisik di desa-desa nelayan, yang pada umumnya masih sangat minim, seperti tidak tersedianya air bersih, jauh dari pasar, dan tidak adanya akses untuk mendapatkan bahan bakar yang sesuai dengan harga standar. Kemiskinan prasarana itu secara tidak langsung juga memiliki andil bagi munculnya kemiskinan keluarga. Misalnya, tidak tersedianya air bersih akan memaksa keluarga untuk mengeluarkan uang untuk membeli air bersih, yang berarti mengurangi pendapatan mereka.

\section{Modal dan Modal Kerja}

Menurut munawir (2014), "Modal adalah hak atau bagian yang dimiliki oleh pemillik perusahaan yang ditujukan dalam pos modal (modal saham), surplus dan laba yang ditahan. Atau kelebihan aktiva yang dimiliki oleh perusahaan terhadap seluruh hutang-hutangnya”. Modal merupakan faktor yang sangat penting dalam perusahaan, karena setiap perusahaan membutuhkan modal dalam menjalankan aktifitasnya. Modal kerja mampu membiayai pengeluaran atau operasi perusahaan sehari-hari. Dengan modal kerja yang cukup akan membuat perusahaan beroperasi secara ekonomis dan efisien serta tidak mengalami kesulitan keuangan. 
Kecukupan modal kerja dapat dievaluasi dengan menggunakan rasio sebagai berikut:

1. Rasio total aktiva terhadap modal kerja bersih (total assets to net working capital). Rasio ini menunjukan rasio total aktiva terhadap modal kerja bersih. Rasio yang tinggi mengindikasikan rendahnya tingkat likuiditas, sedangkan rasio yang rendah mengindikasikan tingkat likuiditas yang tinggi. Rasio ini dapat diukur dengan menggunakan rumus:

Total asset to net working capital ratio $=\frac{\text { Total Asset }}{\text { Net working capital }}$

2. Rasio kewajiban lancar (current liabilities to net working capital ratio).

Rasio ini merupakan ekspresi alternative dari current ratio. Bila current ratio rendah, rasio ini akan tinggi, mengindikasikan likuiditas tinggi, rasio ini dapat diukur dengan menggunakan rumus:

Current liabilities to net working capital

$$
\text { ratio }=\frac{\text { Current liabilities }}{\text { Net working capital }}
$$

3. Perputaran modal kerja (working capital turnover).

Working capital turnover atau perputaran modal kerja merupakan rasio yang digunakan untuk mengukur aktivitas bisnis terhadap kelebihan aktiva lancar atas kewajiban lancar.
Rasio yang tinggi mengindikasikan likuiditas yang rendah untuk mendukung operasional, sedangkan rasio yang rendah akan menunjukan likuiditas yang tinggi. Rasio ini dapat diukur dengan menggunakan rumus sebagai berikut :

Working capital turnover ratio $=$

$$
\frac{\text { Revenue }}{\text { Net working capital }}
$$

\section{Metode Penelitian}

Pendekatan yang digunakan dalam penelitian ini yaitu pendekatan kualitatif. Pendekatan kualitatif adalah proses penelitian yang didasarkan pada fakta sosial alamiah (naturalistik) dengan penelitian sebagai instrumen kunci, data deskriptif, tidak berdasarkan pada analisis statistik dan dilaporakan secara naratif. Dalam penelitian, teknik pengumpulan data merupakan faktor penting demi keberhasilan penelitian. Hal ini berkaitan dengan bagaimana cara mengumpulkan data, siapa sumbernya, dan apa alat yang digunakan.

Metode pengumpulan data yang digunakan dalam penelitian ini adalah dengan cara melakukan wawancara dengan para nelayan di desa Ngalipaeng II. Sumber data yang digunakan dalam penelitian ini yaitu data primer dan sekunder. Data primer yaitu data yang diperoleh peneliti secara 
langsung dari sumber aslinya yang berupa wawancara, jajak pendapat dari individu atau kelompok maupun hasil observasi dari suatu obyek, kejadian atau hasil pengujian. Fokus penelitian adalah teknis operasional pelaksanaan pendekatan kualitatif yang didasarkan pada judul, rumusan masalah, dan tujuan penelitian. Adapun fokus penelitian ini adalah pentingnya modal kerja dalam meningkatkan usaha nelayan di Kampung Ngalipaeng II kecamatan Manganitu Selatan Kabupaten Kepulauan Sangihe.

Informan penelitian adalah orang atau pihak tertentu diluar penulis yang menguasai tema atau masalah penelitian. Dengan kata lain informan kunci dimana yang bersangkutan sangat menguasai materi atau tema yang sedang diteliti. Dengan demikian penentuan informan dalam penelitian ini tidak dibatasi tetapi disesuaikan dengan kebutuhan penelitian. Keterangan dari informan yang satu akan dibandingkan dengan keterangan dari informan lain guna memperoleh informasi yang valid. Adapun para informan tersebut adalah:

1. Kepala desa/kampung Ngalipaeng II

2. Nelayan

3. Nelayan paling lama

4. Penjual

5. Pembeli.

\section{Deskripsi Lokasi Penelitian}

Seiring dengan perkembangan pemerintahan maka pada tahun 2002 telah terbentuk lembaga yang baru yang disebut Majelis Tua - Tua Kampung ( MTK ) yang beranggotakan 5 orang dengan ketua Jakson Domensilidan pada tahun 2007 kembali 5 orang anggota MTK yang baru yang di ketuai oleh A.Makalisang dengan periode 6 tahun .

Lembaga Kemasyarakatan yang semula disebut Lembaga Sosial Desa yang kemudian dirubah menjadi Lembaga Ketahanan Masyarakat Desa ( LKMD) yang diketuai oleh B . Rompas kemudian digantikan oleh K. Bomboia . dalam perkembangang selanjutnya LKMD dirubah menjadi Lembaga Ketahanan Masyarakat ( LKM ) yang diketuai oleh D.J. Jacob . Sedangkan untk kegiatan perempuan dikampung telah dibentuk Tim Penggerak PKK sejak masa pemerintahan P.A. Izaak sampai saat ini yang diketuai oleh istri kepala kampung yang memerintah.

Kampung Ngalipaeng I adalah kampung yang terletak di pesisir pantai bagian selatan wilayah Kecamatan Manganitu Selatan Kabupaten Kepulauan Sangihe, dengan batas - batas wilayah sebagai berikut :

Utara : Berbatasan dengan kampung Tumalede 
Timur : Berbatasan dengan kampong Ngalipaeng 1 lindongan 2

Selatan : Berbatasan dengan laut Sulawesi

Barat : Berbatasan dengan kampung Ngalipaeng 1 lindongan 1.

\section{Hasil Penelitian}

Karakteristik responden di gunakan untuk mengetahui keragaman dari responden berdasarkan jenis kelamin, usia dan status pekerjaan. Hal tersebut dapat memberikan gambaran yang cukup jelas mengenai kondisi dari responden.

\section{Tabel 3. Responden berdasarkan usia}

\begin{tabular}{lll}
\hline & Responden & Usia \\
\hline 1 & Kepala Desa/Kampung & 36 Tahun \\
2 & Nelayan & 48 tahun \\
3 & Nelayan & 39 tahun \\
4 & Nelayan paling lama & 60 tahun \\
5 & Nelayan paling lama & 67 Tahun \\
6 & Penjual & 40 tahun \\
7 & Penjual & 45 tahun \\
8 & Pembeli & 43 Tahun \\
\hline
\end{tabular}

Berdasarkan karakteristik usia responden pada tabel 3. tersebut menunjukan bahwa: responden yang berusia 36 tahun 1 orang, responden yang berusia 39 tahun 1 orang, responden yang berusia 40 tahun 1 orang, responden yang berusia 43 tahun 1 orang, responden yang berusia 45 tahun 1 orang, responden yang berusia 48 tahun 1 orang, responden yang berusia 60 tahun 1 orang, responden yang berusia 67 tahun 1 orang.
Tabel 4. Responden berdasarkan jenis Kelamin

\begin{tabular}{lll}
\hline NO & Responden & Jenis Kelamin \\
\hline 1 & Kepala Desa/Kampung & Laki - laki \\
2 & Nelayan & Laki - laki \\
3 & Nelayan & Laki - laki \\
4 & Nelayan Paling lama & Laki - laki \\
5 & Nelayan paling lama & Laki - laki \\
6 & Penjual & Perempuan \\
7 & Penjual & Perempuan \\
8 & Pembeli & Perempuan \\
\hline
\end{tabular}

Berdasarkan karakteristik jenis kelamin responden pada tabel 4, menunjukan bahwa responden yang berjenis laki-laki sebanyak 5 orang, responden yang berjenis perempuan sebanyak 3 orang.

\section{Tabel 5. Responden Berdasarkan Status}

\begin{tabular}{lll}
\hline No & Responden & Status \\
\hline 1 & Kepala Desa/Kampung & Menikah \\
2 & Nelayan & Menikah \\
3 & Nelayan & Menikah \\
4 & Nelayan paling lama & Menikah \\
5 & Nealayan paling lama & Menikah \\
6 & Penjual & Menikah \\
7 & Penjual & Menikah \\
8 & Pembeli & Menikah \\
\hline
\end{tabular}

Berdasarkan karakteristik status responden pada tabel 5. Tersebut, menunjukan bahwa semua status responden sudah menikah.

\section{Tabel 6. Responden berdasarkan}

\section{Pendapatan}

\begin{tabular}{lll}
\hline No & Responden & Pendapatan \\
\hline 1 & Kepala Desa/kampong & 2.600.000 ribu 1 bulan \\
2 & Nelayan & 500 ribu 1 minngu \\
3 & Nelayan & 500 ribu 1 minggu \\
4 & Nelayan paling lama & 1 juta 1 bulan \\
5 & Nelayan paling lama & 2 juta 1 bulan \\
6 & Penjual & 300 ribu 1 minggu \\
7 & Penjual & 300 ribu 1 minggu \\
8 & Pembeli & 500 ribu-1 Juta 1 \\
\hline
\end{tabular}


Berdasarkan karakteristik pendapatan responden pada tabel 6 tersebut, menunjukan bahwa pendapatan responden rata rata dari Rp.300.000 - Rp.500.000 per minggu dan Rp. 1.000.000 - Rp.2.600.000 per bulan.

Tabel 7. Penduduk menurut jenis kelamin

\begin{tabular}{lllll}
\hline \multirow{2}{*}{ No. } & \multirow{2}{*}{ Desa/Kampung } & \multicolumn{2}{c}{ Penduduk } & Jumlah \\
\cline { 3 - 5 } & & Laki-laki & Perempuan & \\
\hline \multirow{2}{*}{1} & Ngalipaeng II & 459 & 404 & 863 \\
\hline & & & 863 \\
\hline
\end{tabular}

Pada tabel 7 diatas dapat dilihat bahwa jumlah pendudk di kampung Ngalipaeng II Kecamatan Manganitu Selatan Kabupaten Kepulauan Sangihe adalah 863 jiwa yang terdiri dari laki-laki 459 jiwa dan penduduk perempuan 404 jiwa.

Tabel 8. Banyaknya Penduduk Menurut Mata Pencaharian

\begin{tabular}{llllll}
\hline No & Desa/Kampung & Petani & Nelayan & Pedagang & PNS \\
\hline 1 & Ngalipaeng II & 135 & 489 & 16 & 9
\end{tabular}

Berdasarkan pada tabel 8 diatas dapat dilihat bahwa penduduk yang mata pencaharian sebagai petani 135 orang, penduduk yang mata pencaharian sebagai nelayan 489 orang, penduduk yang mata pencharian sebagai pedagang 16 orang, penduduk yang bekerja sebagai PNS 9 orang. Penduduk yang mata pencaharian paling banyak adalah sebagai Nelayan.
Tabel 9. Banyaknya Bangunan Rumah Berdasarkan Jenisnya

\begin{tabular}{llllll}
\hline No & $\begin{array}{l}\text { Desa/Kamp } \\
\text { ung }\end{array}$ & $\begin{array}{l}\text { Rumah } \\
\text { Permane } \\
\mathrm{n}\end{array}$ & $\begin{array}{l}\text { Rumah } \\
\text { Semi } \\
\text { Permane } \\
\mathrm{n}\end{array}$ & $\begin{array}{l}\text { Ruma } \\
\mathrm{h} \\
\text { Kayu }\end{array}$ & $\begin{array}{l}\text { Rumah } \\
\text { Bambu } \\
\text { (Lainny } \\
\text { a) }\end{array}$ \\
\hline 1 & $\begin{array}{l}\text { Ngalipaeng } \\
\text { II }\end{array}$ & 30 & 261 & 53 & 88 \\
\hline
\end{tabular}

Berdasarkan tabel 9 diatas dapat dilihat bahwa jumlah bangunan rumah permanen 30 rumah, jumlah bangunan semi permanen 261 rumah, jumlah bangunan rumah kayu 53 rumah, jumlah bangunan rumah bamboo (lainnya) 88 rumah.

\section{Pembahasan}

Kondisi Masyarakat Nelayan di Kampung Ngalipaeng II di hubungkan dengan Modal kerja Usahanya. Masyarakat Nelayan di Kampung Ngalipaeng II identik dengan kemiskinan, banyak hal yang menyebabkannya yaitu kurangnya modal usaha yang dimiliki para nelayan lebih khusus usaha hasil nelayan. Dengan tidak tersedianya modal kerja yang memadai maka nelayan tidak akan mampu meningkatkan produksi serta biaya operasional. Keterbatasan akses terhadap modal, rendahnya posisi tawar dalam proses pemasaran, keterbatasan sarana dan prasarana pendukung, dan rendahnya penanganan hasil tangkapan. Hal ini ditunjukkan oleh banyaknya masyarakat pesisir khususnya nelayan yang belum mampu memenuhi kebutuhan hidupnya 
dan keluarga karena terkadang sedikitnya hasil tangkapan yang di peroleh oleh nelayan dan terlalu murahnya harga tangkap ikan nelayan yang mengakibatkan sedikitnya pendapatan yang diterima.

Dibidang sarana dan prasarana, seperti fasilitas umum dan fasilitas ekonomi, masih terbatas. Lemahnya sarana dan prasarana dalam mendukung terciptanya akses pasar bagi produk-produk perikanan dan kelautan daerah yang bersangkutan. Lemahnya pemasaran menjadi permasalahan utama karena frekuensi keterkaitannya dengan permasalahan lain paling tinggi. Hal ini berimplikasi pada pemasaran produk perikanan tersebut tidak dapat mengandalkan pasar lokal tetapi harus diarahkan pada pasar antar daerah dan tujuan ekspor.

\section{Simpulan}

Banyak masyarakat nelayan yang belum bisa memenuhi kebutuhan hidup rumah tangga, pendidikan, dan kebutuhan lainlain. Karna mengingat hasil dari usaha nelayan yang begitu rendah/kurang karena keterbatasan biaya dan modal kerja.

\section{Untuk Pemerintah Kabupaten}

Kepulauan Sangihe terutama Dinas Perikanan untuk dapat memberikan perhatian dan bantuan kepada Nelayan guna mendorong peningkatan usaha nelayan di kampung Ngalipaeng

Kecamatan Manganitu Selatan.

\section{Referensi}

Sastrawidjaya. (2002). Nelayan Nusantara. Pusat Riset Pengolahan Produk Sosial Ekonomi Kelautan dan Perikanan: Jakarta : PPM

Nitisusastro, M. (2009). Kewirausahaan \& Manajemen Usaha Kecil, Penerbit Alfabeta Bandung

Perry, M. (2002) Mengembangkan Usaha Kecil, Penerbit PT. Rajagrafindo Persada, Jakarta

Ginting, D. (1996). Pengelolaan Sumberdaya Wilayah Pesisir dan Lautan secara Terpadu, PT. Pradnya Paramita, Jakarta, 305 hal.

Dahuri, R. (2000), Pembangunan Kawasan Pesisir dan Lautan, Tinjauan Aspek Ekologis dan Ekonomi. Jurnal Ekonomi Lingkungan.

Dahuri, R. (2003), Paradigma bans Pembangunan Indonesia berbasis Kelautan. Orasi Ilmiah : Guru besar tetap bidang pengelolaan sumberdaya Pesisir dan Lautan Fakultas Perikanan dan Ilmu Kelautan Institut Pertanian Bogor.

Gunarso, W. (1985). Tingkah laku Ikan Dalam Hubungan Dengan Metode dan Taktik Penangkapan. Jurnal Pemanfaatan Sumberdaya Perikanan Fakultas Perikanan IPB, Bogor. 43 hal.

Haluan, J, dan Nuraeni, T.W., (1988). Penerapan Metode Skoring dalam Pemilihan Teknologi Penangkapan Ikan Yang Sesuai Untuk Dikembangkan Di Suatu Wilayah Perairan, Bulleting Jurusan PSP, IPB Bogor, Volume II, No. $1 ; 3$ - 16 
Jurnal Administrasi Bisnis (JAB)

Vol. 9. No. 3, 2019

(p-ISSN 2338-9605; e-2655-206X)

Kusnadi, (2000), Nelayan : Strategi Adaptasi dan Jaringan Sosial, Bandung : Humaniora Utama Press.

Kusnadi, (2009). Keberdayaan Nelayan dan Dinamika Ekonomi Pesisir, Yogyakarta; Ar,Ruzz Media. 